\title{
Further Studies on a Mosaic Virus of Cowpea from Puerto Rico
}

\author{
J. Enrique Pérez and Amelia Cortés-Monllor'
}

\section{INTRODUCTION}

Pérez and Cortés-Monllor in a previous paper $(10)^{2}$ reported on a cowpea mosaic virus (PRCMV) ${ }^{3}$ having properties and a host range similar to those of Sheperd's Arkansas cowpea mosaic virus (ACMV) $(12,13)$. PRCMV also resembled a cowpea mosaic virus from Venezuela described by Debrot and Rojas ( 7 ). In this paper we present additional data on other characters of PRCMV as well as its serological relationship to ACMV and the Trinidad cowpea mosaic virus (TCMV) $(4,6)$.

\section{MATERIALS AND METHODS}

\section{VIRUSES}

A culture of TCMV was obtained from Dr. R. F. Barnes of the University of the West Indies, St. Augustine, Trinidad. ACMV was furnished by Dr. Hubert J. Walters, University of Arkansas, Fayetteville, Ark. PRCMV was isolated in Puerto Rico (10).

\section{PARTIAL PURIFICATION OF VIRUSES}

Groups of about 600 plants of cowpea cultivar (cv.) Blackeye were dusted with carborundum 600 , then inoculated separately on the primary leaves with each of the three above-mentioned viruses. After 2 weeks, when the leaves had developed distinct mosaic symptoms, they were cut and frozen for 2-3 days. The leaves were then homogenized in a cold Waring Blendor in $1.5 \mathrm{ml}$. cold $0.1 \mathrm{M}$ phosphate buffer $\mathrm{pH} 7.0 \mathrm{per} \mathrm{g}$. of tissue. The juice was extracted through cheesecloth (crude extract). One volume of butanol and 1 volume of chloroform were added to 2 volumes of crude extract with continuous stirring for 1 hour in an ice-bath. The mixture was then centrifuged in an International UV model centrifuge, using the No. 240 head at 1,200 gravities $(g)$ to break the emulsion. The top layer, which consisted of the aqueous phase, was carefully removed and pooled. This was clarified by

1 Bacteriologist and Assistant Bacteriologist, respectively, Agricultural Experiment Station, Mayaguiez Campus, University of Puerto Rico, Río Piedras, P.IR.

2 Italic numbers in parentheses refer to Literature Cited, p. 190-1.

${ }^{3}$ In our previous paper (10) the cowpea mosaic virus from Puerto Rico was designated as CoMV. However, for uniformity and clarity of expression, it is designated as PRCMV in this paper because the Arkansas and Trinidad cowpea mosaic viruses are respectively designated as ACMV and TCMV. 
centrifuging for 20 minutes at $5,750 \mathrm{~g}$ in the No. 30 rotor of the Spinco model $\mathrm{L}$ ultracentrifuge. The clarified suspension then was centrifuged at $92,033 \mathrm{~g}$ for 2.5 hours. The supernatant was discarded and the pellets were resuspended in distilled water using $1 / 4$ volume of the crude extract. An additional cycle of differential centrifugation was given to remove contaminants. The pellets from the high-speed run were resuspended in distilled water using $1 / 5$ volume of the crude extract. The resuspended pellets were clarified as before and 8-percent polyethylene glycol (9) plus $0.3 \mathrm{M}$ sodium chloride added to the clarified supernatant to precipitate the virus. The precipitate was left overnight in the refrigerator. It was then packed by centrifuging at $11,700 \mathrm{~g}$ in the No. 30 rotor. The supernatant was discarded and the precipitate dissolved in $70 \mathrm{ml}$. distilled water. Clarification at $5,750 \mathrm{~g}$ for 10 minutes was carried out as before and the precipitation process repeated. The final precipitate was dissolved in $5 \mathrm{ml}$. of $0.01 \mathrm{M}$ phosphate buffer $\mathrm{pH}$ 7.0 per $100 \mathrm{ml}$. of crude extract. A final clarification was given by centrifuging for 10 minutes at $11,700 \mathrm{~g}$. The supernatant (virus solution) was of a bluish white color. When inoculated on Chenopodium amaranticolor after dilution in $0.01 \mathrm{M}$ phosphate buffer $\mathrm{pH}$ 7.0, the ACMV preparation induced local lesions up to a dilution of $10^{-6}$, the TCMV at a dilution of $10^{-6}$, and the PRCMV at $10^{-7}$ dilution.

\section{SEROLOGY}

\section{PREPARATION OF ANTISERA}

White New Zealand rabbits were bled to obtain normal serum before injection with the purified viruses. One rabbit was used for each preparation. The rabbits first were given multiple small subcutaneous injections using a total of $4 \mathrm{ml}$. of each purified virus preparation emulsified in Freund's complete adjuvant (Difco). An intramuscular injection with adjuvant was given 3 weeks after the first subcutaneous injections, with a final intramuscular injection given 2 weeks later. Three weeks after the final injection, the rabbits were bled. The sera were frozen and stored until used.

\section{PRECIPITIN TESTS}

Tube precipitin tests were used to determine the titers of the 3 antiserit, both against their homologous and heterologous antigens. Dilutions of each antiserum were made, ranging from $1 / 10$ to $1 / 2560$. Then an equal volume of purified virus solution was added to each tube. The dilution of each of the purified virus solutions used was the one preceding the endpoint after previous titration with its homologous antiserum. The tests were read after 2 hrs. incubation in a water bath set at $37^{\circ} \mathrm{C}$. and then after overnight refrigeration. 


\section{GEL DIFFUSION TESTS}

For the agar gel diffusion tests, the Ouchterlony method was employed (3) and the following medium was prepared as follows: Solution A-1 g. Ionagar No. 2 was dissolved in $100 \mathrm{ml}$. of 0.85 percent saline by boiling and then $10 \mathrm{~g}$. Thimerosal added. Solution B-5 mg. of Amido Black were dissolved in $5 \mathrm{ml}$. saline. Both solutions were mixed in the proportion of $1 \mathrm{ml}$. of $\mathrm{B}$ to $100 \mathrm{ml}$. of A. After the solution had reached a temperature near $40^{\circ} \mathrm{C}$., 30 to $35 \mathrm{ml}$. were poured on a glass plate $63 / 4$ inches long by $4 \frac{1}{2}$ inches wide and allowed to harden. Then three reaction areas were made in the agar by cutting six wells with a No. 1 flamed cork borer around three central wells of the same size. In each reaction area the distance between each of the
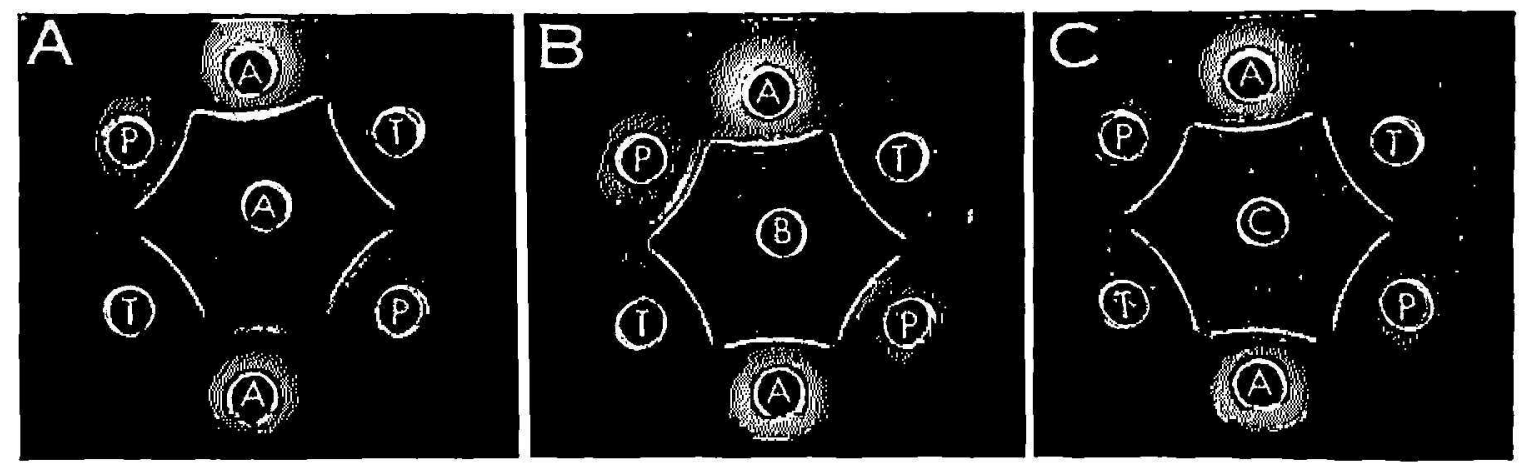

Frg. 1.-Agar gel diffusion tests with Puerto Rico, Arkansas, and Trinidad cowpen mosaic viruses. The center wells contain antiserum to: A, Puerto Rico cow pea mosaic virus; $B$, Arkansas cowpea mosaic virus; and $C$, Trinidad cowpea mosaic virus. The outer wells contain purified preparations of the viruses: P, Puerto Rico; A, Arkansas; and $\mathrm{T}$, Trinidad cowpea mosaic viruses.

outer six wells and the cent ral well was $10 \mathrm{~mm}$. One of the central wells was filled with PRCMV antiserum (fig. 1,A), the next central well with ACMIV antiserum (fig. 1,B), and the third well with TCMV antiserum (fig. 1,C). Opposite outer wells of each reaction area were filled with PRCMIV, ACMIV, and TCMV antigens (fig. 1,P,A,T). Formaldehyde at a final concentration of 0.1 percent was used to preserve the viral antigens. The glass plate then was incubated at $28^{\circ} \mathrm{C}$. inside a glass chamber and pieces of watersoaked absorbent cotton placed inside the chamber to maintain a humid atmosphere. Photographs were taken of the reaction areas after 24 hrs. incubation.

\section{PASSIVE HEMAGGLUTINATION TEST (PHA)}

The passive hemagglutination test was performed following the method described by Abu Salih et al. (1). Tanned sheep red cells were sensitized separately with globulin from antiserum against each of the three cowpea 
mosaic viruses. Concentrations of globulin used ranged from 10 to 0.2 percent. It was found that the optimal concentrations of globulin necessary for sensitization ranged from 2.5 to 5 percent. This had to be determined experimentally for each antiserum.

\section{RESISTANCE OF PRCMV TO ACETONE AND ETHER}

Crude sap was extracted from leaves of Phaseolus vulgaris cv. Charleroi systemically infected by PRCMV (10). The crude sap was extracted as described before, 14 days after inoculation of the plants and mixed separately with 1 volume of acetone and 1 volume of ether. The mixtures then were shaken for 3 minutes and centrifuged at 2,000 r.p.m. in a No. 813 angle head (International UV centrifuge). The precipitates formed were each separately rubbed onto carborundum-dusted primary leaves of three Blackeye cowpea plants. All the plants developed characteristic mosaic symptoms. The remaining supernatants were left in the refrigerator $\left(8^{\circ} \mathrm{C}\right.$.) for 3 days. It then was observed that precipitates had been formed in both the acetone and ether supernatants. These precipitates then were packed by centrifugation at 2,000 r.p.m. The supernatants and pellets obtained from this centrifugation were each inoculated onto four plants of cowpea cv. Blackeye.

\section{SEROLOGICAL DETECTION OF VIRUS IN PRIMARY AND TRIFOLIATE LFAVES}

Thirty cowpea plants cv. Blackeye were inoculated with PRCMV on their primary leaves as previously described. Twenty plants of the same age were left as uninoculated controls. Seven and 14 days after inoculation the primary and trifoliate leaves of both the inoculated and control plants were cut separately with scissors. In each case the sap was expressed by grinding in separate steam-sterilized mortars. Each sap then was diluted in 0.85 percent sodium chloride in twofold steps. One ml. amounts of the dilutions of sap from primary and from trifoliate leaves were separately added to tubes containing an equal volume of a 1/50 dilution of PRCMV antiserum. The mixtures were incubated in a $37^{\circ} \mathrm{C}$. water bath for $2 \mathrm{hrs}$.

\section{RESULTS}

The results of the tube precipitin tests are shown in table 1. From this table it may be seen that there is a close antigenic relationship between PRCMV, ACMV and TCMV. However, the homologous reactions between the three antigens and their respective antisera were one-twofold step higher than the heterologous reactions thus showing that the viruses are not completely identical. These results are similar to those obtained by Sheperd (12).

Results of the agar-gel diffusion tests also confirm the relationship be- 
tween the three viruses. In the case of the reactions between three antigens and the antiserum against TCMV, single coalescent lines of precipitation can be seen. However, in the reaction between PRCMV and ACMV viruses with $B$ antiserum, two lines of precipitation are observed between the wells $P$ and $A$ on the upper part of figure 1,B but not on the lower. This probably is due to very small differences in the quantity of the preparations

TABLE 1.-Precipitin lests with antisera to partially purified cowpea viruses from Arkansas (ACMV), Puerlo Rico (PRCMV) and Trinidad (TCMV)

\begin{tabular}{|c|c|c|c|c|c|c|c|c|c|c|}
\hline \multirow{2}{*}{$\begin{array}{l}\text { Antiserum } \\
\text { to- }\end{array}$} & \multirow{2}{*}{ Antigenl } & \multicolumn{9}{|c|}{ Dilutions of antisera } \\
\hline & & $1 / 10$ & $1 / 20$ & $1 / 40$ & $1 / 80$ & $1 / 160$ & $1 / 320$ & $1 / 640$ & $1 / 1280$ & $1 / 2560$ \\
\hline ACMV & $\begin{array}{l}\text { ACMV } \\
\text { PRCMV } \\
\text { TCMV }\end{array}$ & $\begin{array}{l}+ \\
+ \\
+\end{array}$ & $\begin{array}{l}+ \\
+ \\
+\end{array}$ & $\begin{array}{l}+ \\
+ \\
+\end{array}$ & $\begin{array}{l}+ \\
+ \\
+\end{array}$ & $\begin{array}{l}+ \\
+ \\
+\end{array}$ & $\begin{array}{l}+ \\
+ \\
+\end{array}$ & $\begin{array}{l}+ \\
- \\
-\end{array}$ & $\begin{array}{l}- \\
-\end{array}$ & $\frac{-}{-}$ \\
\hline PRCMV & $\begin{array}{l}\text { PRCMV } \\
\text { ACMV } \\
\text { TCMV }\end{array}$ & $\begin{array}{l}+ \\
+ \\
+\end{array}$ & $\begin{array}{l}+ \\
+ \\
+\end{array}$ & $\begin{array}{l}+ \\
+ \\
+\end{array}$ & $\begin{array}{l}+ \\
+ \\
+\end{array}$ & $\begin{array}{l}+ \\
+ \\
+\end{array}$ & $\begin{array}{l}+ \\
+ \\
+\end{array}$ & $\begin{array}{l}+ \\
+ \\
+\end{array}$ & $\begin{array}{l}+ \\
-\end{array}$ & $\frac{-}{-}$ \\
\hline TCMV & $\begin{array}{l}\text { TCMV } \\
\text { ACMV } \\
\text { PRCMV }\end{array}$ & $\begin{array}{l}+ \\
+ \\
+\end{array}$ & $\begin{array}{l}+ \\
+ \\
+\end{array}$ & $\begin{array}{l}+ \\
+ \\
+\end{array}$ & $\begin{array}{l}+ \\
+ \\
+\end{array}$ & $\begin{array}{l}+ \\
+ \\
+\end{array}$ & $\begin{array}{l}+ \\
+ \\
+\end{array}$ & $\begin{array}{l}+ \\
+ \\
+\end{array}$ & $\begin{array}{l}+ \\
-\end{array}$ & $\begin{array}{l}- \\
-\end{array}$ \\
\hline
\end{tabular}

1 Partially purified preparations of ACMV, PRCMV and TCMV each at a concentration of $0.05 \mathrm{mg} . / \mathrm{ml}$.

TABLE 2.-Titers of ACMV, TCMV and PRCMV when lested by the precipitin and $P H A$ methods

\begin{tabular}{cccc}
\hline Virus & Titer by precipitin test & Titer by PHA test & Sensitivity increase \\
\hline ACMV & $640^{1}$ & $163,840^{2}$ & 256 \\
TCMV & 1,280 & 655,360 & 512 \\
PRCMV & 1,280 & 655,360 & 512 \\
\hline
\end{tabular}

1 Reciprocal of dilution.

inside the wells and should be regarded as artifacts. This does not detract from the clearly-seen coalescent lines which prove relationship between the three viruses, as stated above.

In table 2, a comparison is made between the titers obtained in the precipitin tests and those obtained from the passive hemagglutination test (PHA). It can be seen that the titers given by the PHA tests are much higher than those given by the precipitin tests. The values for increase in sensitivity were found by dividing titers obtained from the PHA tests by 
those obtained from the precipitin tests. These values approximate those obtained by other authors (1) using different methods.

\section{RESISTANCE OF PRCMV TO ACETONE AND ETHER}

After an observation period of $\mathbf{1 7}$ days, the results showed that although the acetone supernatant was non-infectious, the acetone precipitate had induced symptoms in all of the inoculated plants. Chant (4) reported that TCMV was not affected by a 50-percent solution of acetone. On the other hand, both the supernatant and precipitate from the ether extraction of PRCMV were still infectious to Blackeye cowpea plants.

\section{SEROLOGICAL DETECTION OF VIRUS IN PRIMARY AND TRIFOLLATE LEAVES}

The results showed that the virus content, as determined by the precipitin tests, was greater in the primary than in the trifoliate leaves. In leaves cut 7 days after inoculation the precipitin titer of the infective sap from the primary leaves was $1 / 80$; in leaves cut 14 days after inoculation the titer had increased to $1 / 320$. Although the sap from trifoliate leaves had a titer of $1 / 10,7$ days after inoculation of the primary leaves, and in spite of the fact that it had increased to $1 / 80$ after 14 days, it was four times lower than the titer reached during the same period in the primary leaves. Leaves from healthy plants did not react with antiserum.

\section{DISCUSSION}

The data reported in our previous publication (10) strongly suggested a close relationship between Sheperd's Arkansas cowpea mosaic virus (ACMV) and PRCMV. The additional findings reported herein also demonstrate relationship between PRCMV and the Trinidad cowpea mosaic virus (TCMV). This is clearly borne out by the results with the precipitin tests of the three antisera with their homologous and heterologous antigens; the endpoints of the antisera to the heterologous antigens were very close to the endpoints reached with the homologous antigens. The relationship seems to be close if consideration is given to the fact that in the gel-diffusion tests the precipitation lines show coalescence between the heterologous and homologous antigens when tested against the three different antisera in the central wells.

The passive hemagglutination test $(1,11)$ proved to be the most sensitive method for the detection of the three viruses, as shown by the difference in titers (table 2). PRCMV was unaffected by treatment with acetone, another character which makes it similar to TCMV (4). In addition, it was found that the virus is not affected by ether. 
The fact that the serological titer of PRCMV in the primary (inoculated) leaves was higher than in the systemically infected ones is in agreement with recent findings employing other methods, that directly inoculated leaves contain more virus than those systemically infected $(5,8,14)$.

\section{SUMMARY}

A mosaic virus of cowpea from Puerto Rico was found to be closely related serologically to cowpea mosaic viruses from Arkansas and Trinidad. This was demonstrated both by gel-diffusion and tube precipitin tests with partially purified preparations of the virus. The passive hemagglutination test again proved to be a highly sensitive method for detection of plant virus antigens. The virus content of directly inoculated leaves was proven serologically to be higher than the virus content of systemically infected leaves.

\section{RESUMEN}

Se encontró que un virus del mosaico del fréjol está relacionado serológicamente con los virus del mosaico del fréjol de Arkansas y Trinidad. Esto se comprobó mediante pruebas de precipitación en agar gel y en tubos de precipitina, usando preparaciones purificadas de los tres virus. La prueba de hemaglutinación pasiva fue altamente sensitiva en cuanto a detectar los antígenos virosos. Se probó, también, por el método de precipitinas que el contenido de virus de las hojas inoculadas es mayor que el de las hojas infectadas sistémicamente.

\section{LITERATURE CITED}

1. Abu Salih, H. S., Murant, A. F., and Daft, M. J., Comparison of passive haemagglutination and bentonite flocculation tests for serological work with plant viruses, J. Gen. Virol. \&: 155-66, 1968.

2. Agrawal, H. O., Identification of cowpea mosaic virus isolates, Meded. Landbouw. Wageningen 64 (5) : 1-53, 1964.

3. Ball, E. M., Serological tests for the identification of plant viruses, Committee on Plant Virology, Amer. Phytopathological Soc., 1961.

4. Chant, S. R., Further studies on the host range and properties of Trinidad cowpea mosaic virus, Ann. Appl. Biol. 60: 159-62, 1962.

5. Copeman, R. J., Hartman, J. R., and Watterson, J. C., Tobacco mosaic virus concentration in inoculated and systemically infected tobacco leaves, Phytopathology $59:$ 1,012-3, 1969.

6. Dale, W. T., Observations on a virus disease of cowpea in Trinidad, Ann. Appl. Biol. 96 : 327-33, 1949.

7. Debrot, E. C. and Rojas, C. E. B., El virus del mosaico del frijol, Vigna sinensis Endl. (cowpea mosaic virus) en Venezuela, Agr. Trop., Revista del Centro de Investigaciones Agronómicas, Maracay, Venezuela 17 (1): 3-15, 1967.

8. Delgado-Sánchez, S. and Grogan, R. G., Purification and properties of potato virus Y, Phytopathology 56 (12): 1,397-1,404, 1966. 
9. Hebert, T. T., Precipitation of plant viruses by polyethylene glycol, Phytopathology 58 (3): $362,1963$.

10. Pérez, J. E. and Cortés-Monllor, A., A mosaic virus of cowpea from Puerto Rico, Plant Dis. Reptr. 54 (3): 212-6, 1970.

11. Saito, Y. and Iwata, Y., Hemagglutination test for titration of plant virus, Virology 22: 426-8, 1964.

12. Sheperd, R. J., Properties of a mosaic virus from cowpea and its relationship to the bean pod mottle virus, Phytopathology 54 (4): 466-73, 1964.

13. - Serological relationship between bean pod mottle virus and cowpea mosaic viruses from Arkansas and Trinidad, Phytopathology 53 (7): 865-6, 1963.

14. Tomlinson, J. A., Sheperd, R. J., and Walker, J. C., Purification, properties and serology of cucumber mosaic virus, Phytopathology $49: 292-9,1959$. 